\title{
Barriers to digital marketing adoption at remote rural tourism destinations in Sarawak: an exploratory study
}

Sharon Cheuk*a, Azuriaty Atang ${ }^{\mathrm{b}}$, Lo May Chiun ${ }^{\mathrm{c}}$, T. Ramayah ${ }^{\mathrm{d}}$

Senior Lecturer, Universiti Malaysia Sarawak (Author a)

Lecturer, Universiti Malaysia Sarawak (Author b)

Professor, Universiti Malaysia Sarawak (Author c)

Professor, Universiti Sains Malaysia (Author d)

*Corresponding author email: ccssharon@unimas.my

*Corresponding author address: Universiti Malaysia Sarawak, 94300 Kota Samarahan, Sarawak, Malaysia

*Corresponding author telephone: +60-82-584419

Acknowledgement: The funding of this research is obtained through a Research Acculturation Collaborative Effort (RACE) Grant Scheme (Race/e(1)/1328/2016(1)) from the Ministry of Education, Malaysia.

\begin{abstract}
Rural tourism has been shown to benefit local communities from the economic perspective. Digital marketing allows marketing information to be transmitted directly to potential visitors without the need for an intermediary, in a low-cost but effective way. Rural tourism destinations in Sarawak now have an opportunity to benefit from the Sarawak state government's initiative, the Digital Sarawak Centre of Excellence, in terms of digital content creation and website maintenance. However, the current level of adoption is zero to minimal in rural tourism destinations. This study examines the barriers towards digital marketing adoption from the perspective of rural tourism providers. Fieldwork was performed at two sites, Ba'kelalan and Long Lamai, in July 2016 and February 2017 respectively. In-depth interviews were conducted with a total of 19 respondents. The study revealed that tourism providers currently depended on word-of-mouth recommendations or direct contact for bookings, but were willing to adopt digital marketing with the assistance of knowledgeable parties. However, certain physical, logistical and social constraints may have a detrimental effect on the community's readiness level to entertain tourists on a larger scale and may further impede the overall progress of digital marketing adoption, at both the individual and destination levels.
\end{abstract}

Keywords: Digital marketing adoption; Tourism Service Providers; Rural Tourism

\section{1}

\section{Introduction}

Tourism has been envisaged to greatly benefit rural communities from the economic and social perspective, especially in bringing employment/income opportunities and much-needed regeneration (Kotler, Haider, \& Rein, 1993; Liu, 2006; Sharpley, 2002). However, a rural destination may not be well-recognised in the tourism marketplace, and hence tourists need to be made aware of its existence as well as its tourism potential prior to visiting. Destination marketing that is effective will, therefore, promote rural tourism by increasing tourist arrivals; tourists would be also more satisfied, return to a particular destination, as well as recommend the said destination to others (Ekinci \& Hosany, 2006; Murphy, Moscardo, \& Benckendorff, 2007). Digital marketing has been noted as a low-cost and effective method of providing essential information to target customers (Garren, 2012); such information can include those of a visual nature (Choi, Lehto, \& Morrison, 2007; Greaves \& Skinner, 2010). As such, digital marketing can bypass the physical barriers of transmitting information transmission to the intended market, a feature particularly important for rural tourism destinations.

In Malaysia, ICT in general, and telecentres in particular, have helped to advance tourism at rural destinations (Lo, Mohamad, Songan, \& Yeo, 2012). More recently, the Sarawak statement government has, via the setting up of the Digital Sarawak Centre of Excellence (DSCOE), led an initiative towards the digital transformation of the state economy. The DSCOE would be involved in research and development by partnering with higher education institutions and industry players. Tourism has been earmarked as a priority sector in this initiative (Aubrey, 2017). In view of the rural tourism destinations' need for effective digital marketing and the availability of the state government initiative, rural tourism destinations should capitalise on the opportunities presented and profit from them accordingly (Chua, 2017). 